\title{
PENCEGAHAN, PERLINDUNGAN DAN PENANGANAN KEKERASAN TERHADAP ANAK DAN REMAJA
}

\author{
Ulfah Farida Kustanty \\ STAIN Syaikh Abdurrahman Siddik Bangka Belitung, Indonesia \\ E-mail: ulfah.fk81@gmail.com
}

\begin{abstract}
This article is motivated by violence that occurs in children and adolescents who can negatively influence if not sought and anticipated factors that influence it. In general, this article aims to identify and analyze the prevention, protection and treatment of violence against children and adolescents. Violence is an act committed by a person or a number of people who are strongly positioned to a person or a number of people who are weak (weak/weak), whose means of strength, both physically and non-physically deliberately committed to cause suffering to the object of violence. What makes children vulnerable to violence are: unharmed families, parents who abuse addictive substances or suffer mental disorders, neglect or neglect, inappropriate or aggressive behavior in the classroom, fail or be less accountable to schools, limited social skills and join friends who use alcohol or drugs or participate in other risky behaviors. Actions that can be done include: Preventive action, educative action, curative action and rehabilitative action. In this issue the role of parents, community, and government is very important to make children and adolescents physically and mentally healthy and able to live in society appropriately.
\end{abstract}

Keywords: Violence; victims; children and adolescents

Abstrak. Artikel ini dilatarbelakangi oleh kekerasan yang terjadi pada anak dan remaja yang dapat berpengaruh negatif jika tidak dicari dan diantisipasi faktor-faktor yang mempengaruhinya. Secara umum artikel ini bertujuan untuk mengetahui dan menganalisis pencegahan, perlindungan dan penanganan kekerasan terhadap anak dan remaja. Kekerasan adalah suatu tindakan yang dilakukan oleh seseorang atau sejumlah orang yang berposisi kuat (merasa kuat) kepada seseorang atau sejumlah orang yang berposisi lemah (dipandang lemah/ dilemahkan), yang dengan sarana kekuatannya, baik secara fisik maupun non-fisik dengan sengaja dilakukan untuk menimbulkan penderitaan kepada obyek kekerasan. Yang menyebabkan anak rentan menjadi korban kekerasan adalah : keluarga yang tidak harmonis, orang tua yang menyalahgunakan zat adiktif atau menderita gangguan mental, pengabaian atau penelantaran, perilaku tak pantas atau agresif di kelas, gagal atau kurang bertanggung jawab pada sekolah, kecakapan sosial yang terbatas dan ikut teman yang menggunakan alkohol atau narkoba atau ikut serta dalam perilaku yang beresiko lainnya. Tindakan yang dapat dilakukan diantaranya adalah : tindakan Preventif, tindakan edukatif, tindakan kuratif dan tindakan rehabilitatif. Dalam permasalahan ini peran orang tua, masyarakat, dan Pemerintah sangatlah penting untuk menjadikan anak dan remaja sehat fisik dan mental dan dapat hidup di masyarakat dengan sewajarnya.

Kata Kunci: Kekerasan; korban; anak dan remaja

Permalink/DOI: https://doi.org/10.15408/harkat.v14i2.12817 


\section{Pendahuluan}

Tidak dapat di pungkiri bahwa sampai saat ini belum ada kata sepakat dari semua stakeholders tentang perlindungan anak. Indikatornya jelas, yaitu masih banyaknya kekerasan yang dilakukan terhadap anak-anak sampai sekarang ini dengan berbagai dalih pembenaran. Banyak orang tua yang masih menerapkan hukuman fisik kepada anak yang "katanya" merupakan disiplin terhadap anakanak nya. Namun yang terjadi kemudian, bukannya anak patuh kepada orang tua sebaliknya anak akan kebal terhadap hukuman. Dengan adanya kekerasan yang semakin berulang membuat orang tua semakin keras memberikan hukuman sehingga menimbulkan dampak fisik dan psikis yang membuat anak semakin menderita. Hal ini tidak hanya terjadi di lingkungan keluarga saja tapi juga terjadi di lingkungan masyarakat bahkan lingkungan sekolah yang kita anggap sebagai tempat kedua anak untuk menjadi manusia yang bermoral atau individu yang ber-etika.

\section{Pengertian Kekerasan}

Kata 'kekerasan' menjadi salah satu kata yang lazim dipergunakan untuk menjelaskan beberapa persoalan yang terkait dengan perlakuan atau tindakan yang dipandang tidak menyenangkan, tidak manusiawi, bertentangan dengan norma/nilai tertentu atau hukum. Kekerasan adalah hal yang bersifat atau berciri keras yaitu perbuatan seseorang yang menyebabkan cedera atau menyebabkan kerusakan fisik atau barang orang lain atau paksaan (M. Marwas dan Jimmi P, 2009 : 258).

Kekerasan adalah suatu tindakan yang dilakukan oleh seseorang atau sejumlah orang yang berposisi kuat (merasa kuat) kepada seseorang atau sejumlah orang yang berposisi lemah (dipandang lemah/ dilemahkan), yang dengan sarana kekuatannya, baik secara fisik maupun non-fisik dengan sengaja dilakukan untuk menimbulkan penderitaan kepada obyek kekerasan (Mufidah dkk, 2006 : 2). Menurut Sugihastuti dkk, kekerasan merupakan suatu bentuk tindakan yang dilakukan terhadap pihak lain, yang pelakunya perseorangan atau lebih, yang dapat mengakibatkan penderitaan bagi pihak lain (Sugihastuti, dkk, 2007 : 171).

Secara umum kekerasan diartikan sebagai setiap perilaku yang dapat menyebabkan keadaan perasaan atau tubuh (fisik) menjadi tidak nyaman. Perasaan tidak nyaman ini berupa kekhawatiran, ketakutan, kesedihan, ketersinggungan, kejengkelan atau kemarahan. Keadaan fisik tidak nyaman ini dapat berupa lecet, luka, memar, patah tulang, dan sebagainya (Lusi Nuryanti, 2008 : 72).

Bentuk-bentuk kekerasan yang terjadi di masyarakat diantaranya adalah kekerasan berbasis budaya, kekerasan berbasis etnis, kekerasan berbasis agama, kekerasan berbasis politik dan kekerasan berbasis gender. Adapun perbedaan dengan tindak kriminal murni, kekerasan ini lebih condong pada perilaku pembenaran atas tindakan agresifnya, sementara kriminal adalah tindakan nyata yang disebut sebagai kejahatan pada umumnya, dan tindak kriminal itu disertai juga dengan perilaku kekerasan (Mufidah dkk, 2006 : 2).

\section{Pengertian Anak dan Remaja}

Anak-anak, sesuai dengan UU Perlindungan Anak (UUPA) No. 23 Tahun 2002 pasal 1 ayat 1 adalah seseorang yang belum berusia 18 (delapan belas) tahun termasuk anak yang masih dalam kandungan (Kementerian PP RI, 2002 : 9). Selanjutnya pasal 19 Konvensi Hak Anak (KHA) menyebutkan bahwa segala bentuk kekerasan mental dan fisik, cedera atau penggunaan, penelantaran atau perlakuan yang menjadikan anak terlantar, perlakuan salah atau 
eksploitasi serta penyalahgunaan seksual, adalah kekerasan terhadap anak.

Ada beberapa nilai anak yang hidup dan terus berkembang, yaitu pandangan bahwa anak adalah amanah Tuhan yang harus dirawat, diasuh, dan dididik sesuai potensi yang dimiliki. Pandangan yang lebih religius ini melihat anak bukan sekadar keturunan biologis dari seseorang tetapi Tuhan yang harus dijaga keberadaan dan kelangsungan hidupnya (Sri Lestari, 2012 : 45).

Allah SWT telah menitipkan anak dalam jiwa manusia, rasa cinta yang dalam kepada anak dan tak tertandingi dengan cinta lain. Sebab anak merupakan jantung hati, cahaya kalbu di dalam rumah tangga. Ini bisa dilihat dari perhatian besar yang diberikan orang tua kepada anak-anak mereka, disertai dengan rasa kasih sayang yang abadi (Yudian Wahyudi dkk, 1993 : 191). Pada sisi lain, anak-anak diberikan kewajiban untuk menjaga norma-norma yang telah dibangun generasi terdahulu. Anak memang memiliki nilai sejarah untuk mewarisi peradaban, tetapi dia juga memiliki nasib dan takdirnya sendiri yang tidak boleh diganggu gugat orang tua. Anak memiliki dunia sendiri, memilki alamnya sendiri, yang mungkin tidak dikenali orang tua. Maka orang tua hanya bertugas memberikan ruang seluas-luasnya dan stimulan agar mencapai pertumbuhan dan perkembangan yang optimal. Dalam kajian psikologi, anak bukanlah manusia dewasa dalam bentuk mini. Dia adalah pribadi otonom yang sedang berproses menemukan jati dirinya. Tugas orang dewasa adalah membantu anak tumbuh kembang dan memberikan pencerahan agar dia menemukan takdir dirinya, dan bukan membekuk, menjajah, menindas, dan mengalahkannya sehingga anak harus persis melakukan seperti apa yang dikehendaki orang dewasa.

Anak mempunyai empat hak dasar, yaitu : Pertama, Hak untuk Hidup. Anak-anak harus mempunyai akses pada pelayanan kesehatan dan dapat menikmati standar hidup yang layak, cukup makanan, air bersih dan tempat tinggal yang aman; Kedua, Hak untuk Tumbuh dan Berkembang. Anak-anak berhak mendapatkan kesempatan untuk mengembangkan potensinya semaksimal mungkin. Mereka berhak memperoleh pendidikan (formal dan non formal) yang memadai. Anak-anak juga diberi kesempatan untuk bermain, berekreasi dan beristirahat; Ketiga, Hak untuk memperoleh Perlindungan. Anak-anak harus dilindungi dari eksploitasi ekonomi dan seksual, kekerasan fisik dan mental serta segala bentuk diskriminasi. Anak-anak yang tidak mempunyai orang tua dan anak-anak pengungsi juga berhak mendapat perlindungan; Keempat, Hak untuk Berpartisipasi. Anak-anak harus diberi kesempatan untuk menyuarakan pandangan dan ide-idenya terutama tentang berbagai persoalan yang berkaitan dengan anak (Mufidah, dkk : 2006, 18).

Masa remaja merupakan peralihan dari anak-anak menuju dewasa, baik secara jasmani maupun rohani. Masa ini disebut juga sebagai pubertas yakni masa ketika seorang anak mengalami perubahan fisik, psikis, dan pematangan fungsi seksual. (Moh. Abdurrouf, dkk : 2005, 1) Remaja sebetulnya tidak mempunyai tempat yang jelas. Ia tidak termasuk golongan anak, tetapi ia tidak pula termasuk golongan orang dewasa atau golongan tua. Remaja ada diantara anak dan orang dewasa. Remaja masih belum mampu untuk menguasai fungsi-fungsi fisik maupun psikisnya (F.J. Monks, dkk : 2002, 259).

\section{Landasan Hukum Perlindungan dan Kesejahteraan Anak}

Perlindungan hukum bagi anak dapat diartikan sebagai upaya perlindungan hukum terhadap berbagai kebebasan dan hak asasi manusia anak (Fundamental Right and Freedoms of Children) serta berbagai 
kepentingan yang berhubungan dengan kesejahteraan anak. Perlindungan anak adalah segala kegiatan untuk menjamin dan melindungi anak dan hak-haknya agar dapat hidup, tumbuh, berkembang, dan berpartisipasi secara optimal sesuai dengan harkat dan martabat kemanusiaan, serta mendapat perlindungan dari kekerasan dan diskriminasi.

Dasar hukum di Indonesia untuk melindungi korban kekerasan berbasis gender diantaranya adalah Undang-undang No.1 tahun 1946, tentang Kitab Undang-Undang Hukum Acara Pidana (KUHAP), Undang-undang No. 39/ 1999, Kepres No. 129/1998 Program Aksi Nasional Hak Asasi Manusia Indonesia (19982001), Inpres No. 9/2000 tentang Pengarusutamaan Gender dalam Pembangunan Nasional, dan Undang-Undang No. 23 tahun 2002, tentang Perlindungan Anak.

Meskipun undang-undang nomor 39 tahun 1999 tentang Hak Asasi Manusia telah mencantumkan hak anak, pelaksanaan kewajiban dan tanggung jawab orang tua, keluarga, masyarakat, pemerintah dan negara untuk memberikan perlindungan, namun masih diperlukan undang-undang mengenai perlindungan anak sebagai landasan yuridis bagi pelaksanaan dan tanggung jawab tersebut. Oleh karena itu melalui UU RI No. 23 tahun 2002 tentang Perlindungan Anak diharapkan dapat melindungi anak dari berbagai bentuk kekerasan (Mufidah, dkk : 2006, 14).

Dalam UU RI Nomor 23 Tahun 2002, Bab I pasal 1 ditegaskan bahwa anak adalah seseorang yang belum berusia 18 tahun, termasuk anak yang masih dalam kandungan. Sedangkan pada pasal 2 ditegaskan juga bahwa perlindungan anak adalah segala kegiatan untuk menjamin dan melindungi anak dan hak-haknya agar dapat hidup, tumbuh, berkembang; dan berpartisipasi, secara optimal sesuai dengan harkat dan martabat kemanusiaan, serta mendapat perlindungan dari kekerasan dan diskriminasi (UU.RI Nomor 23 tahun 2002 : 2002, 9).

\section{Pencegahan Kekerasan Terhadap Anak dan Remaja}

Kekerasan terhadap Anak menjadi masalah yang serius. Anak merupakan makhluk ciptaan Allah SWT yang wajib dilindungi dan dijaga kehormatan, martabat dan harga dirinya secara wajar, baik secara hukum, ekonomi, politik, sosial, maupun budaya tanpa membedakan suku, agama, ras dan golongan. Segala bentuk perlakuan yang mengganggu dan merusak hakhak anak dalam berbagai bentuk kekerasan, diskriminasi dan eksploitasi yang tidak berperikemanusiaan harus dihapuskan tanpa kecuali.

Agar kekerasan terhadap anak dan remaja dapat diminimalisir bahkan dihilangkan maka perlu mengetahui lembaga-lembaga yang dapat memberikan informasi tentang kekerasan terhadap perempuan dan anak antara lain ditingkat nasional misalnya Komnas Perempuan, Koalisi Perempuan Indonesia (KPI), LBH Apik, Yayasan Jurnal Perempuan, Puan Amal Hayati dan sejenisnya. Di tingkat daerah antara lain : LSM advokasi, WCC (Women Crisis Center), LSM Perempuan, LBH, Pusat Studi Wanita di Perguruan Tinggi, RPK (Ruang Pelayanan Khusus) di kepolisian, PPT (Pusat Pelayanan Terpadu) di rumah sakit dan sebagainya. Layanan pendampingan dapat berbentuk pendampingan hukum, medis, psikologis, agama, dan penguatan ekonomi pasca krisis. Layanan ini dapat dilakukan secara sinergis antara lembaga pemerintah dengan LSM dan masyarakat (Mufidah, dkk : 2006, 75). 


\section{Perlindungan Kekerasan Terhadap Anak dan Remaja}

Posisi anak dalam rumah tangga kerap berada pada posisi lemah. Di bawah kontrol orang yang memiliki wewenang dalam menentukan kehidupannya, misalnya ayah, ibu saudara yang lebih tua/ kuat yang seharusnya memberikan perlindungan, membimbing, memberikan kasih sayang dan mendidiknya dengan cara-cara yang bijak, tetapi kekuasaan tersebut sering disalahgunakan sehingga anak menjadi rentan mendapatkan kekerasan. Permasalahan yang sering muncul pada anak adalah tentang banyaknya Eksploitasi Seksual Komersial Anak (ESKA) adalah penggunaan anak untuk tujuan seksual seksual dengan imbalan atau dalam bentuk lain antara anak, pembeli jasa seks, perantara atau agen, dan pihak lain yang memperoleh keuntungan dari perdagangan seksualitas anak tersebut (Mufidah, dkk : 2006, 21).

Ada 3 (tiga) bentuk ESKA yang terjadi di masyarakat yaitu : (1) Prostitusi anak, didefinisikan sebagai penggunaan anak dalam kegiatan seksual dengan pembayaran atau dengan imbalan dalam bentuk lain; (2) Pornografi anak, yaitu setiap representasi dengan sarana apapun pelibatan secara eksplisit seorang anak dalam kegiatan seksual baik secara nyata maupun disimulasikan, atau setiap representasi dari organ seksual anak untuk tujuan seksual; (3) Perdagangan anak untuk seksual, yaitu merupakan rangkaian kegiatan penipuan atau bujukan, atau penyalahgunaan kekuasaan atau penculikan yang disertai ancaman, paksaan, penculikan atau bentuk-bentuk lain dari penggunaan kekerasan dan kekuatan untuk menguasai anak, yang dimulai dari perekrutan, pemindahan, transportasi atau pengiriman, penampungan sementara atau penampungan di tempat tujuan untuk diperdagangkan seperti praktik perbudakan (Mufidah, dkk : 2006, 22).
Penanganan Kekerasan Terhadap Anak dan Remaja

Hampir sama dengan kasus kekerasan psikis pada perempuan, anak-anak jarang yang mengakui secara langsung bahwa ia telah mengalami kekerasan dan menjadi korban. Situasi di bawah ancaman, lingkungan yang tidak ramah, atau hubungan anak dan orangtua yang eksklusif akan menyebabkan anak memendam peristiwa, enggan bercerita sampai pada suatu kondisi ia telah tidak lagi mampu menyembunyikan peristiwa itu ketika anak mengalami kecelakaan seperti terjadi kehamilan, cacat fisik, terjun ke komunitas gang sebaya dan kasus mencolok lain yang dipilih anak untuk melakukan penyelesaiannya sendiri.

Diharapkan orang-orang terdekat mampu sejak dini mengenali korban dari anak-anak yang mengalami kekerasan. Anak yang sering dilecehkan dan telah mengalami kekerasan biasanya menunjukkan gejala antara lain : takut akan hubungan antar pribadi atau terlalu mengalah/ tunduk; menarik diri, agresif atau aktif secara abnormal (hiperaktif); seringkali lesu atau mudah marah, memisahkan diri; tidak ada rasa sayang atau terlalu menunjukkan rasa sayang.

Ada beberapa gejala yang secara spesifik dapat kita ketahui melalui gejala fisik, seperti : memar, luka bakar, bekas luka/ goretan, bilur, tulang patah, luka-luka yang terus ada; atau tak ketahuan penyebabnya; penyakit yang ditularkan melalui hubungan seksual; luka, pendarahan, atau gatal-gatal di daerah kelamin atau dubur. Gejala melalui perilaku dan kebiasaan ditandai dengan : mimpi buruk; takut pulang ke rumah atau ke tempat lain; takut berada dekat pada orang tertentu; kabur dari sekolah; nakal dan suka berbohong. Sedangkan indikator emosional dapat terdiri dari : depresi, kecemasan terus menerus dan gangguan yang berhubungan dengan stres; fobia (ketakutan yang berlebihan, misalnya takut kegelapan, takut toilet umum, 
takut tertinggal dengan yang lain) termasuk mengisolasi diri, sulit berinteraksi dengan teman sebaya dan orang dewasa; melukai diri sendiri atau harga diri rendah; melukai atau membunuh binatang (Mufidah, dkk : 2006, 99-101).

Beberapa hal yang menyebabkan anak rentan menjadi korban kekerasan adalah : Pertama, keluarga yang tidak harmonis. Kedua, orang tua yang menyalahgunakan zat adiktif atau menderita gangguan mental. Ketiga, pengabaian atau penelantaran. Keempat, perilaku tak pantas atau agresif di kelas. Kelima, gagal atau kurang bertanggung jawab pada sekolah. Keenam, kecakapan sosial yang terbatas. Ketujuh, ikut teman yang menggunakan alkohol atau narkoba atau ikut serta dalam perilaku yang beresiko lainnya.

Dengan adanya kekerasan yang terjadi pada anak dan remaja, maka kita sebagai masyarakat perlu melakukan pendampingan terhadap korban kekerasan agar korban dapat menjalani kehidupannya dengan baik tanpa hambatan dan permasalahan. Beberapa tindakan yang dapat dilakukan diantaranya adalah : Pertama, Tindakan Preventif, untuk mencegah terjadinya kekerasan misalnya sosialisasi penghapusan kekerasan terhadap perempuan dan anak melalui kelompok-kelompok perempuan, organisasi perempuan, LSM, media, atau secara individu melakukan upaya agar siapapun tidak melakukan kekerasan dan tidak menjadi korban kekerasan.

Kedua, Tindakan edukatif, misalnya memberikan pendidikan anti kekerasan dan khususnya yang berbasis gender sejak dini untuk merubah persepsi terhadap kekerasan. Ketiga, Tindakan Kuratif, misalnya jika ada kasus, lembaga atau individu memberikan bantuan untuk memudahkan korban mendapatkan perlindungan, memberikan penguatan mental, dan memberikan informasi yang diperlukan untuk memperoleh layanan pendampingan oleh pihak-pihak yang terkait. Keempat, Tindakan
Rehabilitatif, misalnya membantu pemulihan mental, penguatan ekonomi dan mendorong tumbuhnya proses bersosialisasi dengan lingkungan pasca krisis (Mufidah, dkk : 2006, 76-77).

\section{Dampak dan Realitas Publik Kekerasan terhadap Anak dan Remaja}

Untuk membangkitkan keberpihakan terhadap sensitifitas gender dan kepedulian masyarakat akan pentingnya melindungi anak dan remaja, maka masyarakat perlu melihat lebih jernih dan adil realitas kekerasan yang kebanyakan korbannya adalah anak dan remaja. Oleh karena itu, peta, model, bentuk, dan kuantitas kekerasan terhadap anak dan remaja disajikan agar menstimulasi kesadaran baru bahwa kekerasan terhadap anak dan remaja betul adanya, dan kesadaran itu akan membangkitkan komunitas untuk menghentikan terjadinya korban berkelanjutan.

Bentuk-bentuk kekerasan terhadap Anak yang sering ditemukan adalah : (1) Kekerasan dalam bentuk fisik seperti pemukulan, penganiayaan, penganiayaan yang menyebabkan jatuh sakit, bahkan kematian; (2) Kekerasan psikis seperti ancaman, pelecehan, sikap kurang menyenangkan yang menyebabkan rasa takut, rendah diri, trauma, depresi atau gila; (3) Kekerasan ekonomi, misalnya menerlantarkan anak; (4) Kekerasan seksual berbentuk pelecehan seksual, pencabulan dan pemerkosaan; (5) Eksploitasi kerja dan bentuk pekerjaan terburuk untuk anak; (6) Eksploitasi seksual komersial anak; (7) Trafiking (perdagangan) anak (Mufidah, dkk : 2006, 18-19).

Adapun dampak kekerasan terhadap anak dan remaja dapat dikategorikan menjadi 4 macam yaitu Pertama, Dampak fisik : Luka luka, memar, lecet, gigi rompal, mati, patah tulang, cidera, gangguan fungsional keluhan fisik dan cacat permanen. Kedua, Dampak psikis : 
Sering menangis, sering melamun, tidak bisa bekerja, sulit konsentrasi, gangguan makan, gangguan tidur, mudah lelah, tidak bersemangat, takut/trauma, panik, mudah marah, resah dan gelisah, bingung, menyalahkan diri sendiri, malu, perasaan ingin bunuh diri, merasa tidak berguna, menutup diri, menarik diri dari pergaulan sosial, melampiaskan dendam pada orang lain, melakukan usaha bunuh diri, depresi atau menjadi gila.

Ketiga, Dampak seksual : Kerusakan organ reproduksi, pendarahan, kemungkinan keguguran dua kali lebih tinggi bagi yang hamil, penyakit menular seksual, trauma hubungan seksual, virgiditas, menopause dini dan bisa pula terjadi kehamilan tidak diinginkan (KTD), aborsi (keguguran), penyakit menular seksual seperti HIV/ AIDS. Keempat, Dampak Ekonomis : Kehilangan tempat tinggal dan harus menanggung biaya perawatan medik untuk luka fisik akibat kekerasan (Mufidah, dkk : 2006, 18-19).

Akhir-akhir ini juga banyak terjadi kekerasan terhadap perempuan dan anak yaitu kekerasan dalam rumah tangga (KDRT) dan dalam rumah tangga sebenarnya ada hak untuk dilindungi dari kekerasan dalam keluarga. Pada tahun 1984 pemerintah Indonesia sudah meratifikasi CEDAW menjadi UU No. 7 tahun 1984, yang merupakan penghapusan terhadap bentuk diskriminasi terhadap perempuan di bidang politik, ekonomi, sosial, budaya dan pertahanan keamanan. Tahun 1993 dalam deklarasi PBB disebutkan adanya larangan melakukan empat macam kekerasan (yaitu segala bentuk tindakan yang mengakibatkan kesengsaraan dan penderitaan baik yang dilakukan di depan umum/ publik atau di dalam kehidupan pribadi/ privat), meliputi : (1) kekerasan psikologis atau kejiwaan; (2) kekerasan fisik; (3) kekerasan seksual; (4) kekerasan ekonomi, sehingga pelakunya dapat dituntut dan dijatuhi pidana (Elfi Muawanah : 2009, 126).
Dengan upaya pencegahan, perlindungan dan penanganan kekerasan terhadap anak dan remaja diharapkan dapat meminimalisir hal-hal yang dapat berakibat negatif bagi anak dan remaja. Diperlukan peran beberapa pihak diantaranya adalah orang tua, sekolah, masyarakat dan pemerintah agar anak dan remaja tidak mengalami hambatan dalam proses kehidupan sehari-hari dan dapat menjadi generasi yang berkualitas.

\section{Daftar Pustaka}

Abdurrouf, Moh. dkk. 2005. Masa Transisi Remaja. Jakarta : Triasco Publisher.

Lestari, Sri. 2012. Psikologi Keluarga : Penanganan Nilai dan Penanganan Konflik dalam Keluarga. Jakarta : Kencana.

Marwas, M dan Jimmi P. 2009. Kamus Hukum, Dictionary of Law Complete Edition. Cet I. Surabaya : Reality Publisher.

Monks, F.J, dkk. 2002. Psikologi Perkembangan Pengantar dalam Berbagai Bagiannya. Yogyakarta : Gajah Mada University Press.

Muawanah, Elfi. 2009. Pendidikan Gender dan Hak Asasi Manusia. Yogyakarta : Sukses Offset.

Mufidah, dkk. 2006. Haruskah Perempuan dan Anak Dikorbankan?. Yogyakarta : PT. Pilar Media.

Nuryanti, Lusi. 2008. Psikologi Anak. Jakarta : PT Indeks.

Sugihastuti, dkk. 2007.Gender dan Inferioritas Perempuan (Praktik Kritik Sastra Feminis). Yogyakarta : Pustaka Pelajar.

Undang-Undang Republik Indonesia Nomor 23 Tahun 2002. Jakarta : Kementerian Pemberdayaan Perempuan RI.

Wahyudi, Yudian. dkk. 1993. Keluarga Bahagia dalam Islam. Yogyakarta : CV. Pustaka Mantiq.. 